\title{
Nem-konvencionális gyógymódok a háziorvos szemszögéből
}

\author{
Soós Sándor Árpád dr. ${ }^{1}$ - Eőry Ajándék dr. ${ }^{2}$ - Eőry Ajándok dr. ${ }^{3}$ \\ Harsányi László dr. ${ }^{1}$ - Kalabay László dr. ${ }^{2}$
}

Semmelweis Egyetem, Általános Orvostudományi Kar, ${ }^{1}$ I. Sebészeti Klinika, ${ }^{2}$ Családorvosi Tanszék, Budapest ${ }^{3}$ Magyar Akupunktúra és Moxaterápiás Egyesület, Budapest

Bevezetés: A nem-konvencionális gyógymódokat a betegek igénye tartja fenn, és alkalmazásuk gyakran rejtve marad a családorvosuk előtt. Célkitüzés: Felmérni a családorvosok véleményét a nem-konvencionális gyógymódokról, oktatásukról és integrációjuk lehetőségeiről. Módszer: Önkéntes, anonim kérdőíves felmérés a Semmelweis Egyetem Családorvosi Tanszékének két továbbképző rendezvényén. Eredmények: A 194 háziorvos (39,8\%-os válaszadási arány) 14\%-a rendelkezett természetgyógyász végzettséggel és egynegyedük alkalmazott ilyen módszereket. A válaszadók $45 \%$-a állította, ők vagy családtagjaik betegség esetén igénybe vesznek ilyen gyógymódokat. Döntő többségük $(91,8 \%)$ tudni akart minden, a betegeik által igénybe vett módszerről, ugyanakkor 82,5\%-uk nem tartotta magát elég tájékozottnak a nem-konvencionális gyógymódokkal kapcsolatban. Többségük (86\%) szerint a nem-konvencionális gyógymódokat oktatni kellene az egyetemen. A női nem, húsz évnél rövidebb praxisgyakorlat és a személyes tapasztalat növelte a tanulás iránti igény valószínűségét. Következtetések: A megkérdezett családorvosok jelentős része szeretne tudni a betegeik által alkalmazott nem-konvencionális gyógymódokról, szükségesnek látná ezek oktatását az egyetemen, és speciális csoportjuk szívesen képezné magát ezen a területen. Orv. Hetil., 2015, 156(28), 1133-1139.

Kulcsszavak: nem-konvencionális gyógymódok, természetgyógyászat, családorvos, integratív orvoslás, felmérés

\section{Complementary and alternative medicine from the primary care physicians' viewpoint}

Introduction: The patients initiate the use of complementary and alternative medicine and this often remains hidden from their primary care physician. Aim: To explore general practitioners' knowledge and attitude towards complementary and alternative medicine, and study the need and appropriate forms of education, as well as ask their opinion on integration of alternative medicine into mainstream medicine. Method: A voluntary anonymous questionnaire was used on two conferences for general practitioners organized by the Family Medicine Department of Semmelweis University. Complementary and alternative medicine was defined by the definition of the Hungarian Academy of Sciences and certified modalities were all listed. Results: 194 general practitioners answered the questionnaire (39.8\% response rate). $14 \%$ of the responders had licence in at least one complementary and alternative medicine modalities, $45 \%$ used complementary and alternative medicine in their family in case of illnesses. It was the opinion of the majority $(91.8 \%)$ that it was necessary to be familiar with every method used by their patients, however, $82.5 \%$ claimed not to have enough knowledge in complementary medicine. Graduate and postgraduate education in the field was thought to be necessary by $86 \%$ of the responders; increased odds for commitment in personal education was found among female general practitioners, less than 20 years professional experience and personal experience of alternative medicine. Conclusions: These data suggest that general practitioners would like to know more about complementary and alternative medicine modalities used by their patients. They consider education of medical professionals necessary and a special group is willing to undergo further education in the field.

Keywords: complementary therapies, naturopathy, family practice, integrative medicine, data collection

Soós, S. Á., Ms. Eöry, A., Mr. Eöry A., Harsányi, L., Kalabay, L. [Complementary and alternative medicine from the primary care physicians' viewpoint]. Orv. Hetil., 2015, 156(28), 1133-1139.

(Beérkezett: 2015. február 4.; elfogadva: 2015. május 8.) 


\section{Rövidítések}

AMM = alternatív mozgás- és masszázsterápia; $\mathrm{CAM}=\mathrm{com}$ plementary and alternative medicine; $\mathrm{EBM}=$ evidence-based medicine; ENKK = Egészségügyi Nyilvántartási és Képzési Központ; $\mathrm{HKO}$ = hagyományos kínai orvoslás

A Magyar Tudományos Akadémia Orvosi Osztályának 2010-es állásfoglalása a komplementer medicina megnevezés bevezetését a nemzetközileg általánosan elfogadott és használt 'complementary and alternative medicine' megnevezéssel indokolja. A magyar gyakorlatban emellett mind a természetgyógyászati módszerek, mind pedig a nem-konvencionális gyógymódok kifejezés használatos. Közleményünkben mi ezt a három megnevezést szinonimaként alkalmazzuk.

A nemzetközi terminológiában új fogalom került bevezetésre 'integrative medicine' néven. Ez azt a törekvést jelzi, hogy a természetgyógyászati módszerek a konvencionális orvoslásba integráltan, a hivatalos egészségügyi ellátás keretein belül múködjenek.

A nem-konvencionális gyógyító eljárásokat, ismertebb nevükön természetgyógyászati módszereket a 40/1997. (III. 5.) Kormányrendelet így definiálja: „A nem-konvencionális gyógyító eljárások alkalmazása olyan egészségügyi tevékenység, amely a konvencionális gyógyítási módszereket kiegészíti, meghatározott esetekben helyettesíti" [1]. A Magyar Tudományos Akadémia Orvosi Tudományok Osztályának 2010-es állásfoglalása szerint „nyitottnak kell lenni bármely komplementer terápiás eljárás elfogadására, amennyiben az »evidence-based medicine « $(\mathrm{EBM})$ alapelvei alapján bizonyítható az adott eljárás biztonságossága és hatásossága az adott betegség gyógyításában” [2]. Az állásfoglalás kitér arra, hogy az orvoslásban csak evidenciákon alapuló, hatásos gyógymódokat lehet alkalmazni. A nem-konvencionális gyógymódokat két csoportra osztja: a tudományosan megalapozott gyógymódok (hagyományos kínai orvoslás, manuálterápia, neurálterápia) és a kellố tudományos háttérrel még nem rendelkező gyógymódok (amelyeket az állásfoglalás tovább csoportosít filozófiai alapokon nyugvó módszerekre, tudományosan fel nem tárt módszerekre és csak diagnosztikus módszerekre).

A neurológia tárgykörén keresztül bemutatja, hogy az egyes természetgyógyászati eljárások milyen kórképek esetében alkalmazhatóak. Ez a szándék egyezik azzal a nyugat-európai törekvéssel, hogy az evidenciákkal bizonyítható eljárások automatikusan épüljenek be az egészségügyi ellátórendszerbe, szükségtelenné téve a megkülönböztető definíciókat. Az egyes természetgyógyászati módszerekhez kapcsolódó evidenciákat legszélesebb körben és legszigorúbban a mai napig az Oxford Handbook of Complementary Medicine (Oxford University Press, 2008) tárgyalja [3]. Mindazonáltal az eltérő elnevezések azt is tükrözik, hogy a gyógyításnak ezeket a formáit nem a hagyományos egészségügyi rendszer és nem az orvostársadalom hívta életre. Ezeket a módszereket a betegek igénye tartja fenn, és egyre növekvő népszerúségnek örvendenek világszerte, mint kiegészítő vagy alternatív gyógymódok. Magyarországon egy 1999-ben megjelent, több mint hétezer fóvel készült kérdőíves, országos reprezentációjú felmérés szerint a felnőtt lakosság 15-20\%-a legalább egyszer fordult már természetgyógyászhoz, használt már legalább egyszer valamilyen természetgyógyászati módszert vagy terméket [4]. A National Institute of Health által 2002-ben végzett felmérés szerint világszerte a lakosság legalább $25-70 \%$-a fordul a nem-konvencionális gyógyászathoz [5]. A betegek körében tapasztalható népszerüség felismerése és elismerése eredményeként világszerte növekszik a nemkonvencionális gyógymódok oktatása a graduális és posztgraduális orvosképzésben is [6]. Problémát jelent viszont, hogy a betegek sokszor nem számolnak be arról háziorvosuknak, hogy ilyen módszerekkel élnek, így ez a téma az orvos-beteg kapcsolat homályos pontja marad, kommunikációs akadályként jelenik meg. A hatékony gyógyítás alapfeltétele, hogy az orvos tudjon mindenről, ami a betege gyógyításával és gyógyulásával kapcsolatos. Ennek egyik sarokpontja, hogy az orvos nyitottan forduljon a betege felé, ismerje betege értékrendjét és kulturális hátterét, így páciense számára az optimális gyógymódot tudja javasolni. Ennek nem feltétele, hogy az orvos részletekbe menően ismerje a különböző nemkonvencionális terápiás eljárásokat, de az igen, hogy pozitív hozzáállásával nyitott légkört teremtsen, amiben betege érzi, hogy az orvos támogatóan, pozitívan fordul felé. Fontos azonban, hogy a családorvos ismerje a különböző kezelések együttes alkalmazásának lehetséges mellékhatásait, az egyes terápiák ellenjavallatait, az esetleges interakciókat.

Vizsgálatunk kérdései a nem-konvencionális gyógymódokra vonatkoztak. Célunk volt felmérni a hazai családorvosok e gyógymódokhoz való viszonyulását, ismereteit. Kíváncsiak voltunk arra, mi a véleményük a nem-konvencionális gyógymódok szerepéról az egészségügyi ellátásban, lehetségesnek tartanák-e az integratív medicina alkalmazását, vagyis a nem-konvencionális gyógymódok és a tudományos orvoslás kombinált használatát a mindennapi klinikai gyógyítómunka során. Végül, fontosnak tartanák-e a nem-konvencionális gyógymódokkal kapcsolatos ismeretek oktatását az orvosképzésben, az egyetemen és a későbbiekben.

\section{Módszer}

\section{Minta}

Felmérésünket két, a Semmelweis Egyetem Családorvosi Tanszéke által szervezett konferencián végeztük: 2008ban a siófoki oktatói továbbképzésen és 2010-ben egy kötelező szinten tartó tanfolyamon, Budapesten. Az öszszesen megkérdezett 500 háziorvosból 199 válaszolt (válaszadási arány: 39,8\%). Öt leadott kérdőívet a hiányos kitöltés miatt nem tudtunk értékelni, így az ered- 


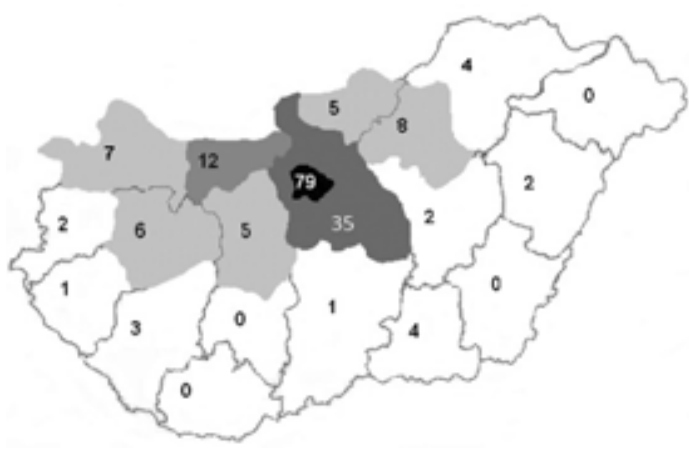

1. ábra A felmérést kitöltő családorvosok praxishelyei, megyénként je-
lölve $(\mathrm{n}=194$ fő $)$

ményeket 194 háziorvos válaszai alapján összegeztük. 63\%-uk Budapestről vagy Pest megyéból érkezett (1. ábra). 46\%-uk Budapesten, 13\%-uk nagyvárosban, 21\%-uk kisvárosban, 20\%-uk falun dolgozott. A válaszadók között a nemek szerinti megoszlás kiegyenlített volt (90 férfi és 104 nő). Átlagéletkoruk 54,2 év (SD: 9,09, 95\% CI: 53-56), a legfiatalabb harminc-, a legidósebb hetvennyolc éves volt. Átlagosan 20 éve (SD: 9,94) dolgoztak praxisban. A válaszadók 32\%-a volt oktató háziorvos, 81\%-uknak volt még a háziorvostan mellett legalább egy szakvizsgája.

\section{A felmérés anyagai}

Magyarországon a természetgyógyászati képzéseket a 11/1997. (V. 28.) NM rendelet szabályozza, és három csoportba rendszerezi: orvosok által végezhető módszerek (HKO, manuálterápia, neurálterápia, továbbá orvosegyetemek által akkreditált egyéb módszerek), gyógytornász által végezhetô manuálterápia és végül felső szintû egészségügyi szakképzés nélkül végezhető természetgyógyászati módszerek [7]. Ez utóbbiakat képzés és vizsga tekintetében az egykori Egészségügyi Szakképzőés Továbbképző Intézet (ETI), ma már Egészségügyi Nyilvántartási és Képzési Központ (ENKK) hatáskörébe sorolta. A 2013. évi CCXLIV. törvény mindezt úgy egészítette ki, hogy a hagyományos kínai orvoslás gyakorlására engedély adható ki 5 éves felsőoktatási képzést követően megszerzett oklevél birtokában [8]. A nemkonvencionális gyógymódokat a törvényi meghatározással definiáltuk. Vizsgálatunkban az MTA állásfoglalásaiban szereplő, illetve az ENKK keretei között elsajátítható nem-konvencionális módszereket a 2.ábrán mutatjuk be és ezek ismeretére, illetve használatára kérdeztünk rá. A kérdőívben emellett nyitott és zárt kérdések szerepeltek. A felmérés önkéntes és anonim volt. (A társadalomtudományi kutatásokhoz a hatályos magyar jogszabályok értelmében nem szükséges TUKEB-engedély.)

\section{Statisztikai elemzés}

Az eredményeket leíró statisztikai elemzés, $\chi^{2}$-próba és logisztikus regresszió felhasználásával kaptuk. Szignifikáns eredménynek a $\mathrm{p}=0,05$ határértéket fogadtuk el. Az adatokat Microsoft Excel programmal rögzítettük, a feldolgozás SPSS 17-es és 19-es programmal történt.

\section{Eredmények}

\section{A háziorvosok személyes viszonyulása} a természetgyógyászati módszerekhez és ismereteik az egyes módszerekrôl

A megkérdezett háziorvosok vagy családtagjaik 44,3\%-a (86 fő) használt saját betegsége esetén természetgyógyá-

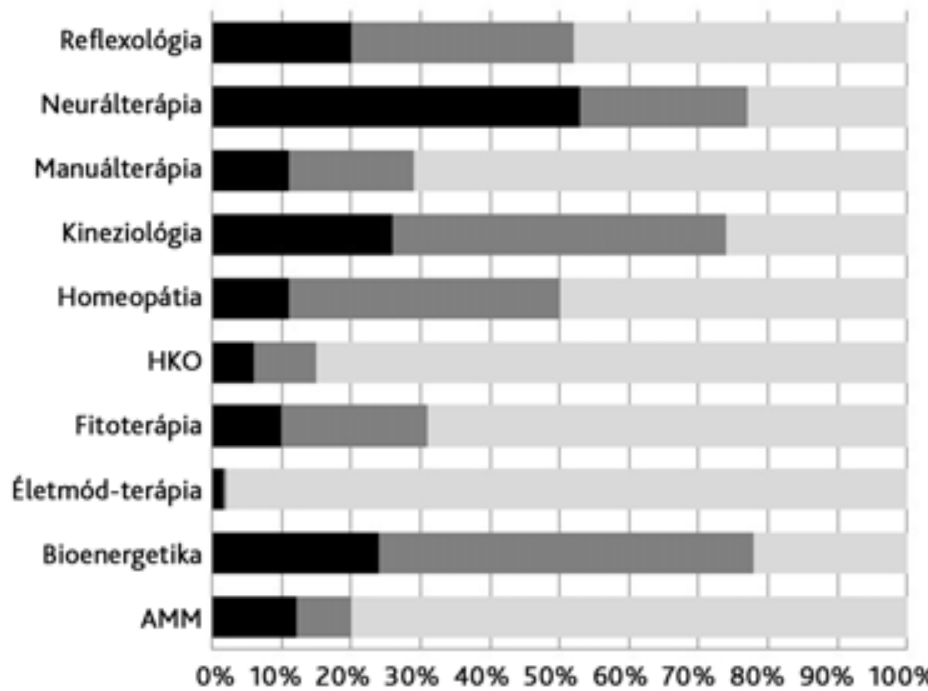

-Nem ismert

=Nem megalapozott

Megalapozott, ajánlott, végzett 
szati módszert. Rendelésén majdnem az összes válaszadó egynegyede (47 fó) alkalmazta ezeket a módszereket, 14\%-uk (27 fó) vizsgázott is valamilyen gyógymódból, tehát ilyen irányú végzettséggel is rendelkezett. A válaszadók 33,5\%-a (65 fó) állította, hogy ismer olyan természetgyógyászt, akiben megbízik és küldene hozzá betegeket.

Értékeltük a kitöltő családorvosok véleményét az egyes nem-konvencionális gyógymódokról. A felsorolt módszereket a „nem ismerem”, „nem tartom megalapozottnak”, „megalapozottnak tartom”, „, betegeimnek javaslom”, „alkalmazom a praxisomban” kategóriákba sorolhatták. Az egyes természetgyógyászati képesítések háziorvosi elfogadottságát a 2. ábrán foglaljuk össze.

A legelfogadottabb módszerek közé tartozik az életmód-terápia, a hagyományos kínai orvoslás (HKO), a manuálterápia és az alternatív mozgás- és masszázsterápia (AMM). Legellentmondásosabb a megítélése a bioenergetika használatának, a kineziológiának és a homeopátiának; míg legkevésbé a neurálterápiát ismerik a megkérdezettek. Az orvosok által használt egyes módszerek százalékos gyakoriságát a 3. ábra mutatja.

\section{Természetgyógyászattal kapcsolatos}

\section{információáramlás a háziorvos-beteg}

\section{kapcsolatban a háziorvosok véleménye szerint}

A kérdőívet kitöltő háziorvosok közül 178 fö (91,8\%) fontosnak tartotta, hogy minden módszerról tudjon, amit betegei felhasználnak a gyógyulás érdekében. Ennek ellenére csak 69 fó $(35,6 \%)$ érezte úgy, hogy betegei minden esetben beszámolnak a nem-konvencionális gyógymódok esetleges használatáról, és 118 fó (60,8\%) gondolta azt, hogy csak részben tájékoztatják őt erről. Az összes válaszadó közül 4 fó állította, nem tud semmit páciensei nem-konvencionális gyógymód használatáról.

\section{Az oktatás és az egészségügyi integráció iránti igény és a megvalósitás lehetséges formái}

Láthattuk, hogy csaknem minden háziorvos fontosnak tartotta, hogy tudja, milyen egyéb módszereket alkalmaznak a betegei. Kérdéses viszont, hogy mennyiben tudnának tanácsot adni betegeiknek ezzel kapcsolatban, ha figyelembe vesszük, hogy a válaszadók 82,5\%-a (160 fó) nem tartotta magát elég tájékozottnak általában a különböző természetgyógyászati kezelések terén. Ezért érdekelt minket az is, hogy e hiányosság kiküszöbölése érdekében a családorvosok szükségesnek tartanák-e ezen gyógymódok elérhetőbb oktatását, a tudományosan megalapozott információszerzést. Kíváncsiak voltunk arra is, hogy a családorvosok szükségesnek tartják-e ezen módszerek egyetemi oktatását. A megkérdezettek a „graduális”, „posztgraduális”, „szakorvosoknak”, „rövid tanfolyam” és „konferencia” lehetőségek közül választhattak. Az eredmény meggyőző volt, szignifikánsan többen gondolták lényegesnek az oktatást $\left(\chi^{2}(1)=5,5\right.$; $\mathrm{p}=0,02)$, a válaszadók $86 \%$-a szerint szükséges oktatni a nem-konvencionális gyógymódokat az egyetemen. Sőt a válaszadók 56,7\%-a (110 fó, $\left.\chi^{2}(1)=10,6 ; \mathrm{p}=0,001\right)$ maga is szívesen tanulna természetgyógyászati módszereket. A tanulás preferált formái hasonlóak voltak azok között, akik maguk is szívesen tanulnának természetgyógyászati módszereket és akik nem. A legkedveltebb formák a graduális, posztgraduális oktatás és a rövid tanfolyamok. A rövid tanfolyamok azok között a legkedveltebbek, akik maguk nem szerettek volna behatóan foglalkozni ezekkel a módszerekkel.

Érdekes kérdésnek tartottuk, hogy mennyire tartanák fontosnak a családorvosok a nem-konvencionális gyógymódok integrálását az egészségügyi ellátásba. A megkérdezettek 72,7\%-a (141 fó) szerint jobban kellene integrálni a nem-konvencionális gyógymódokat Magyarországon is az egészségügyi ellátásba. Nyitott kérdésre adott válaszaikban kiemelték az oktatás és a finanszírozás

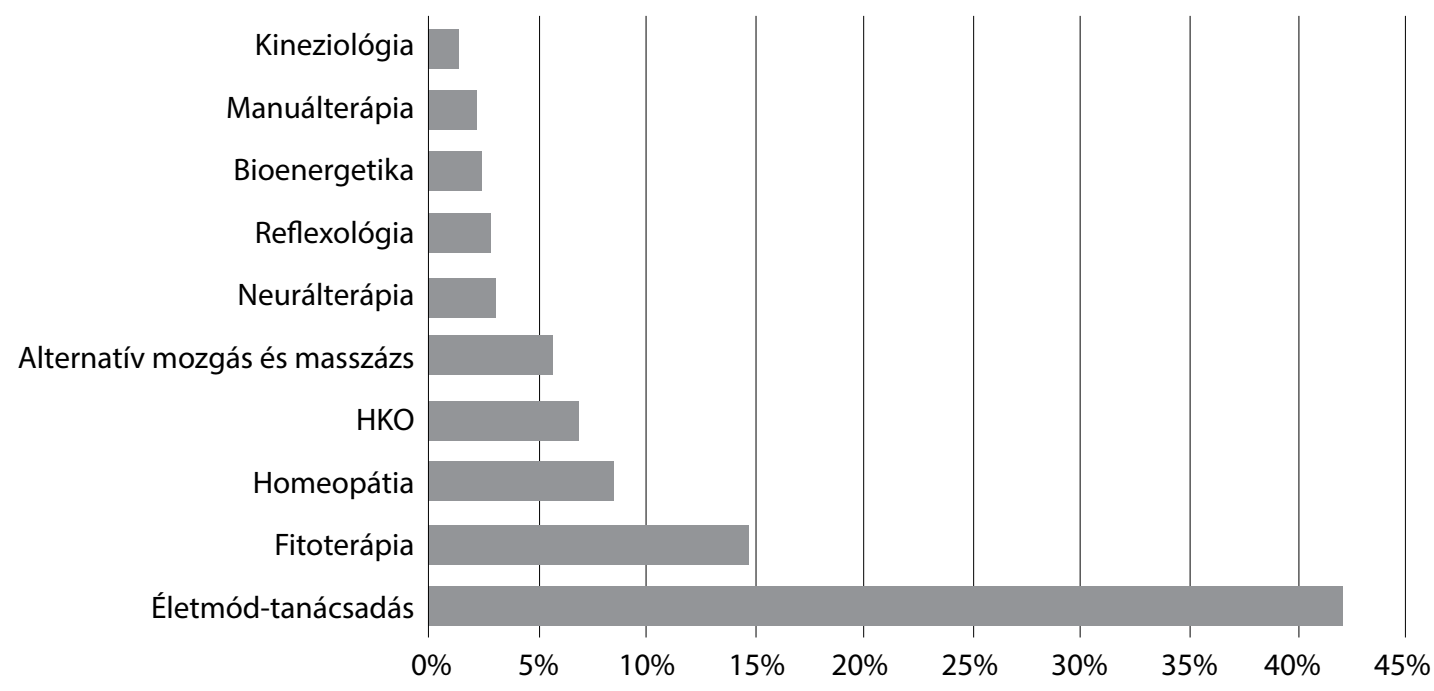

3. ábra $\quad$ A megkérdezett háziorvosok által alkalmazott természetgyógyászati módszerek százalékos megoszlása a vizsgált mintában (n = 194 fő) 
1. táblázat |A tanulási hajlandóság szignifikánsnak talált prediktorai

\begin{tabular}{lcc}
\hline $\begin{array}{l}\text { Tanulási hajlandóság } \\
\text { prediktorai }\end{array}$ & Szignifikancia & Esélyhányados \\
\hline $\begin{array}{l}\text { Fontosnak tartja az } \\
\text { integrációt az egészségügyi } \\
\text { ellátásba }\end{array}$ & $\mathrm{p}=0,001$ & OR: 4,$95 ;(95 \% \mathrm{CI})$ \\
$\begin{array}{l}\text { Nói nem } \\
\begin{array}{l}\text { Ismer megbízható } \\
\text { természetgyógyászt }\end{array}\end{array}$ & $\mathrm{p}=0,003$ & OR: 3,$41 ;(95 \% \mathrm{CI})$ \\
$\begin{array}{l}\text { Alkalmaz } \\
\text { természetgyógyászati } \\
\text { módszert }\end{array}$ & $\mathrm{p}=0,019$ & OR: 5,$26 ;(95 \% \mathrm{CI})$ \\
$\begin{array}{l}\text { Kevesebb mint } 20 \text { éve } \\
\text { dolgozik praxisban }\end{array}$ & $\mathrm{p}=0,025$ & OR: 2,$44 ;(95 \% \mathrm{CI})$ \\
\hline
\end{tabular}

fontosságát, továbbá a szigorú szakmai ellenőrzést és azt, hogy ezeket a gyógymódokat tényleg csak kiegészítésként alkalmazzák.

A kapott eredmények tudatában érdekesnek tartottuk megvizsgálni, hogy van-e olyan tényező, ami meghatározza a tanulási kedvet. Meghatározó tényezőnek találtuk, hogy mióta dolgoznak a családorvosok praxisban. A praxisban eltöltött éveket 10 éves bontásban vizsgálva szignifikáns különbséget kaptunk, amely azt mutatta, hogy a maximum 20 éve praxisban levők (átlagéletkoruk: 50 év, 95\% CI: 48-51,5 év) szignifikánsan nagyobb arányban tanulnának természetgyógyászatot, mint az ennél hosszabb ideje dolgozók $\left(\chi^{2}(3)=15,92 ; p=0,001\right)$.

A felmértek alapján a tanulási hajlandóság prediktorait az 1. táblázatban mutatjuk be. Az oktató és a nem oktató kollégák tanulási kedvét is más és más tényezők határozták meg: a tudományos evidenciák szignifikánsan nagyobb szerepet játszottak az oktató orvosoknál ( $\mathrm{p}=$ 0,02; OR: 2,5), míg a finanszírozás a nem oktató kollégáknál volt nyomós érv ( $\mathrm{p}=0,005$; OR: 2,5$)$.

\section{Megbeszélés}

Az utóbbi években világszerte számos tanulmány vizsgálta az orvosok viszonyulását a nem-konvencionális gyógymódokhoz. Van Haselen és mtsai 2004-ben többek között azt vizsgálták, melyek a leggyakoribb indikációk, amelyekre a családorvosok nem-konvencionális gyógymódokat ajánlanak [9]. A legnyomósabb érveknek a beteg kérését (68\%), a hagyományos kezelés sikertelenségét $(58 \%)$, illetve a nem-konvencionális gyógymódok eredményességére vonatkozó tudományos bizonyítékokat (36\%) találták. A felmérés szerint az alapellátásban dolgozók 66\%-a érdeklődött a nem-konvencionális gyógymódok iránt. A válaszadók mindössze 6\%-a ellenezte a nem-konvencionális gyógymódok integrálását az alapellátásba, a többiek fontosnak tartották ezt. Flannery és mtsai úgy találták egy 2006-ban megjelent felmérésben, hogy a családorvosok 70\%-a érdeklődik a nem-kon- vencionális gyógymódok iránt [10]. Laudenberg és mtsai szerint azonban nemcsak a szakorvosok, hanem a frissen végzett orvosok is érdeklődnek a nem-konvencionális gyógymódok alkalmazása iránt [11]. Családorvos-rezidensek között végzett felmérésük szerint a rezidensek nemcsak érdeklődnek az integratív medicina iránt, hanem örömmel vennék ezek oktatását is, mivel jó lehetőségnek tartják az ilyen jellegú tanfolyamokat személyes és szakmai fejlődésre egyaránt.

A nem-konvencionális gyógymódok népszerüségének növekedése tehát nem helyi jelenség, a fejlett világ legkülönbözőbb országaira jellemző. Nem pusztán az érdeklődés növekszik, hanem a nem-konvencionális gyógymódokkal kapcsolatos bizalom is emelkedik az orvosok között. A nem-konvencionális medicina értékelésekor kiemelt jelentőségű kérdés, hogy az orvosok mely módszereket ajánlanák betegeiknek, melyeket használnák ők maguk is, illetve mi befolyásolja őket véleményük kialakításában. Egy 750 svájci családorvossal készült vizsgálat szerint a válaszadók $62,5 \%$-a $(57,6-67,4 \%)$ javasolta pácienseinek a nem-konvencionális gyógymódokat [12]. A leggyakrabban alkalmazott módszerek a homeopátia, fitoterápia és az akupunktúra volt. Hamilton és mtsai szerint az alapellátásban legelterjedtebben az akupunktúrát és a gyógynövényeket használják [13]. Egy másik tanulmány szerint a családorvosok 39,5\%-a biztosított hozzáférést pácienseinek a nem-konvencionális gyógymódokhoz, a legkönnyebben elérhető módszer az akupunktúra és a homeopátia volt [14]. Pirotta és mtsai azt a kérdést vizsgálták, hogy a családorvosok mely módszereket tanulnák a legszívesebben, illetve mely módszerekben jártasak. A kapott eredmények szerint a legnagyobb érdeklődés a meditáció, akupunktúra és a vitaminterápiákkal kapcsolatban volt, és a fitoterápiával együtt ezekben szereztek már leginkább jártasságot a családorvosok [15]. Egy, a német és angol családorvosi gyakorlatot összehasonlító tanulmány szerint a legnépszerúbb nem-konvencionális gyógymód a kiropraktika és az akupunktúra volt [16]. Joos és munkatársainak vizsgálata szerint, amely 1027 német családorvos válaszain alapul, a leggyakrabban alkalmazott nem-konvencionális gyógymód a neurálterápia, fitoterápia és az akupunktúra [17]. Elmondható tehát, hogy a családorvosok világszerte egyre inkább bizalommal fordulnak a nem-konvencionális gyógymódok felé. A családorvosok szerint az akupunktúra, a homeopátia, a fitoterápia, a neurálterápia és a kiropraktika/ manuálterápia kiemelt jelentőségű nem-konvencionális gyógymód. Ezek az eredmények egybehangzanak saját eredményeinkkel: legjobban az életmód-tanácsadás, az alternatív mozgás- és masszázsterápia, a HKO és a fitoterápia volt elfogadott a felmért családorvosok között. Legkevésbé a neurálterápiát, a bioenergetikát és a kineziológiát javasolnák pácienseiknek. A praxisukban a kineziológia, a manuálterápia és a bioenergetika volt a legritkábban alkalmazott nem-konvencionális gyógymód.

A XXI. század egészségügyi kihívásaira (krónikus, sokszor multimorbid kórállapotok) az Amerikai Egyesült 
Államokban és Nyugat-Európában a klinikai orvoslás olyan új modelljeit vezették be, amelyekben az egészségügyben végzett szigorú tudományos kutatásokra alapozva integrálják a biomedicinát és a komplex emberi természetet a gyógyulás belső folyamataival és a terápiás rendszerek gazdag tárházával. Az integratív medicina olyan gyógyításorientált orvoslás, amely a teljes embert (test, lélek, szellem) veszi figyelembe, beleértve az életmóddal kapcsolatos vonatkozásokat is. A középpontba a terápiás kapcsolatot helyezi, és a megfelelő konvencionális és nem-konvencionális terápiás lehetőségeket egyaránt felhasználja a gyógyításban [18]. Egyre nagyobb az igény mind a betegek, mind az orvosok részéről ezen új szemléletmód bevezetésére. Ezeknek a gyógymódoknak az alkalmazása a praxisokban azonban gyakorta olyan nehézségekbe ütközik, mint az időhiány és a finanszírozás megoldatlansága [19]. Sundberg és mtsai kiemelik az integratív medicina bevezetésének fontosságát [20]. Több tanulmány megjelent, amelyek az integratív medicina szemléletében oktatott családorvos-rezidensek gyógyítómunkájának hosszú távú eredményeit vizsgálják [21, 22]. A képzés eredményeként javult a rezidensek körében az integratív medicina megítélése és javult a páciensekkel kialakított kapcsolat minősége is [23].

Világszerte tehát egyre népszerúbb az alapellátásban a modern, tudományos medicina és a nem-konvencionális gyógymódok együttes, integratív használata. Az új gyógyító szemlélet, az elérhető képzések és a módszerek széles tárháza miatt javulhat a kezelések eredményessége, javul az orvos-beteg kapcsolat, mindez hosszú távon pedig a betegek elégedettségének növekedését és az egészségügyi kiadások csökkenését is eredményezheti.

Vizsgálatunk nem reprezentatív háziorvosi mintán készült, hanem két változatos témájú továbbképző rendezvényen, amelyen nagyobb arányban lehettek jelen a Semmelweis Egyetem Családorvosi Tanszékéhez kötődő háziorvosok, illetve a Budapesten és annak vonzáskörzetében élők. A megkérdezett háziorvosok válaszai hasonló tendenciát mutattak, mint külföldi kollégáiké és nagy valószínúséggel ez az egész hazai alapellátásra jellemző.

Anyagi támogatás: A közlemény megírása és a kapcsolódó kutatómunka anyagi támogatásban nem részesült.

Szerzôi munkamegosztás: A hipotézisek kidolgozásában, a vizsgálat lefolytatásában, a statisztikai elemzésekben és a kézirat megszövegezésében minden szerző egyenlő arányban vett részt. A cikk végleges változatát valamenynyi szerző elolvasta és jóváhagyta.

Érdekeltségek: A szerzőknek nincsenek érdekeltségeik.

\section{Köszönetnyilvánítás}

Szeretnénk köszönetet mondani minden háziorvosnak, aki a kérdőív kitöltésével segített minket a vizsgálat elkészítésében.

\section{Irodalom}

[1] Government Decree No. 40 of 1997 (III. 5) concerning naturopath activity. [40/1997. (III. 5.) Kormányrendelet a természetgyógyászati tevékenységekről.] http://net.jogtar.hu/jr/gen/ hjegy_doc.cgi? docid=99700040.KOR [Hungarian]

[2] Dobozy, A., Kerpel-Fronius, S., Komoly, S., et al.: Complementary medicine - built upon the principles of evidence-based therapy. Discussed and accepted by the Medical Section of the Hungarian Academy of Sciences. [Komplementer medicina - a bizonyítékokon alapuló orvoslás elvei alapján. A Magyar Tudományos Akadémia Orvosi Tudományok Osztályának állásfoglalása.] Orv. Hetil., 2011, 152(30), 1197-1204. [Hungarian]

[3] Ernst, E., Pittler, M. H., Wider, B., et al.: Oxford Handbook of Complementary Medicine. Oxford University Press, Oxford, 2008.

[4] Buda, L.: The analysis of the relationship between alternative medicine and scientific medicine, the socio-psychological and health-sociological background and the complex empirical investigation of its role in the health care. [Az alternatív medicina tudományos orvosláshoz való viszonyának, társadalmi-lélektani, egészség-szociológiai hátterének elemzése és az egészségügyi ellátásban betöltött szerepének komplex empirikus vizsgálata.] PhD-értekezés. Pécsi Tudományegyetem, Általános Orvosi Kar, Pécs, 2003. [Hungarian]

[5] U.S. Department of Health and Human Services: Cancer and Complementary Health Approaches. http://nccam.nih.gov/ health/cancer/camcancer.htm

[6] Konefal, J.: The challenge of educating physicians about complementary and alternative medicine. Acad. Med., 2002, 77(9), $847-850$.

[7] Decree No. 11 of 1997 (V. 28) NM of the Ministry of Welfare concerning certain fields of naturopath activity. [11/1997. (V. 28.) NM rendelet a természetgyógyászati tevékenység gyakorlásának egyes kérdéseiről.] http://net.jogtar.hu/jr/gen/hjegy_ doc.cgi? docid $=99700011$. NM [Hungarian]

[8] Act CCXLIV of 2013 concerning certain changes of acts in the field of health care and health insurance. [2013. évi CCXLIV. törvény az egyes egészségügyi és egészségbiztosítási tárgyú törvények módosításáról.] http://www.hbcs.hu/uploads/jogszabaly/ 1761/fajlok/2013_CCXLIV_torveny_20131224.pdf [Hungarian]

[9] Van Haselen, R. A., Reiber, U., Nickel, I., et al.: Providing complementary and alternative medicine in primary care: the primary care workers' perspective. Complement. Ther. Med., 2004, $12(1), 6-16$

[10] Flannery, M. A., Love, M. M., Pearce, K. A., et al.: Communication about complementary and alternative medicine: perspectives of primary care clinicians. Altern. Ther. Health Med., 2006, $12(1), 56-63$.

[11] Laudenberg, B., Nothnagle, M.: Resident-initiated integrative medicine curriculum in an allopathic family medicine residency. J. Altern. Complement. Med., 2010, 16(7), 799-802.

[12] Déglon-Fischer, A., Barth, J., Ausfeld-Hafter, B.: Complementary and alternative medicine in primary care in Switzerland. [Komplementärmedizin in Schweizer Praxen der Grundversorgung.] Forsch. Komplementmed., 2009, 16(4), 251-255. [German]

[13] Hamilton, J. L., Roemheld-Hamm, B., Young, D. M., et al.: Complementary and alternative medicine in US family medicine practices: a pilot qualitative study. Altern. Ther. Health Med., 2008, $14(3), 22-27$.

[14] Thomas, K. J., Nicholl, J. P., Fall, M.: Access to complementary medicine via general practice. Br. J. Gen. Pract., 2001, 51(462), 25-30.

[15] Pirotta, M. V., Cohen, M. M., Kotsirilos, V., et al.: Complementary therapies: have they become accepted in general practice? Med. J. Aust., 2000, 172(3), 105-109. 
[16] Schmidt, K., Jacobs, P. A., Barton, A.: Cross-cultural differences in GPs' attitudes towards complementary and alternative medicine: a survey comparing regions of the UK and Germany. Complement. Ther. Med., 2002, 10(3), 141-147.

[17] Joos, S., Musselmann, B., Szecsenyi, J.: Integration of complementary and alternative medicine into family practices in Germany: results of a national survey. Evid. Based Complement. Alternat. Med., 2011, 2011, 495813.

[18] Rakel, D. (ed.): Integrative Medicine. 3rd ed. Elsevier, Philadelphia, 2012

[19] Yeh, G. Y., Ryan, M. A., Phillips, R. S., et al.: Doctor training and practice of acupuncture: results of a survey. J. Eval. Clin. Pract., 2008, 14(3), 439-445.

[20] Sundberg, T., Halpin, J., Warenmark, A., et al.: Towards a model for integrative medicine in Swedish primary care. BMC Health Serv. Res., 2007, 7, 107.
[21] Kligler, B., Koithan, M., Maizes, V., et al.: Competency-based evaluation tools for integrative medicine training in family medicine residency: a pilot study. BMC Med. Educ., 2007, 7, 7.

[22] Maizes, V., Silverman, H., Lebensobn, P., et al.: The integrative family medicine program: an innovation in residency education. Acad. Med., 2006, 81(6), 583-589.

[23] Kligler, B., Lebensobn, P., Koithan, M., et al.: Measuring the "whole system" outcomes of an educational innovation: experience from the integrative family medicine program. Fam. Med., $2009,41(5), 342-349$.

(Soós Sándor Árpád dr., Budapest, Üllói út 78., 1082 e-mail: soossandormd@gmail.com)

\section{A rendezvények és kongresszusok híranyagának leadása}

a lap megjelenése előtt legalább 40 nappal lehetséges, a 6 hetes nyomdai átfutás miatt. Kérjük megrendelőink szíves megértését.

A híranyagokat a következő címre kérjük:

Orvosi Hetilap titkársága: Budai.Edit@akkrt.hu

Akadémiai Kiadó Zrt. 